\title{
Effect of Priming on the Growth, Seedling, Yield and its Attributing Characters of Desi Chickpea (Cicer arietinum L.)
}

\author{
Nelakurthi Venkata Praveen*, Prashant Kumar Rai, Rupesh Kumar and Ruksana
}

Department of Genetics and Plant Breeding, Naini Agricultural Institute, Sam Higginbottom University of Agriculture, Technology and Sciences, Prayagraj, 211007 U. P., India

*Corresponding author

\section{A B S T R A C T}

\begin{tabular}{|c|}
\hline Keywords \\
\hline $\begin{array}{l}\text { Chickpea, } \mathrm{KCl} \text {, } \\
\mathrm{NaCl} \text {, Neem leaf } \\
\text { extract, PEG, } \\
\text { Priming and Tulsi }\end{array}$ \\
\hline Article Info \\
\hline $\begin{array}{l}\text { Accepted: } \\
20 \text { August } 2020 \\
\text { Available Online: } \\
10 \text { September } 2020\end{array}$ \\
\hline
\end{tabular}

The experiment was conducted during Rabi season 2018, in order to standardize the best method of priming specific to Chickpea (var. Desi). Four methods of priming vizhydropriming, osmopriming, halopriming, and organic priming with control (Unprimed)were evaluated by screening a range of duration (12 hrs) and concentration viz., $\mathrm{T}_{0-}$ Unprimed Control, hydropriming- $\mathrm{T}_{1^{-}}$Distilled water, osmopriming- $\mathrm{T}_{2^{-}}$ Polyethylene Glycol (PEG) 5\%, $\mathrm{T}_{3}$ - Polyethylene Glycol (PEG) 7\%, $\mathrm{T}_{4}$ - Polyethylene Glycol (PEG) 9\%, halopriming- $\mathrm{T}_{5^{-}}$Sodium Chloride $(\mathrm{NaCl}) 5 \%, \mathrm{~T}_{6^{-}}$Sodium Chloride (NaCl) 7\%, $\mathrm{T}_{7^{-}}$Sodium Chloride $(\mathrm{NaCl})$ 9\%, $\mathrm{T}_{8^{-}}$Potassium Chloride $(\mathrm{KCl}) 5 \%, \mathrm{~T}_{9^{-}}$ Potassium Chloride $(\mathrm{KCl}) 7 \%, \mathrm{~T}_{10}$-Potassium Chloride $(\mathrm{KCl}) 9 \%$, Organic priming- $\mathrm{T}_{11^{-}}$ Tulsi leaf extract $(5 \%), \mathrm{T}_{12-}$ Neem leaf extract $(5 \%)$. It was found that all the priming treatment showed significance difference with the control and the highest germination percent, seedling length, seedling fresh weight, seedling dry weight, vigour indices were observed for Osmopriming with Polyethylene Glycol (PEG) 7\%. Seed pre-sowing seed treatment, used as a simple method for overcoming related to a poor germination and seedling establishment and helps in sustaining agriculture and cost effective and economic, non-toxic, eco-friendly sources.

\section{Introduction}

Pulses maintain the soil fertility by fixing atmospheric nitrogen and improved soil structure. Pulses also play on important role in rainfed agriculture improving physical, chemical and biological properties of soils so considered excellent crop for natural resources management environmental crop diversification and consequently for viable agriculture (Khan et al., 2006). A healthy crop of chickpea can fix up to $141 \mathrm{~kg}$ nitrogen per hectare. Pulse Production, Trade, and consumption of India. Chickpea (Cicer arietinum L.) $2 \mathrm{n}=16$, belongs to family leguminaceae. The word Cicer is a derivative from the Greek word kiros referring to a wellknown roman family Cicero. Arietinum is derived from the Latin word arise meaning ram which refers to the ram's head shape of the chickpea. It is also known as Bengal gram. It is a cool season legume crop and is grown in several countries world-wide as a nutritional crop. 
Chickpea contains protein (22-28\%), fat (4.8$5.5 \%)$, carbohydrates (40-65\%), ash (48\%), moisture (4.9-15.59), vital vitamins like vitamin ' $\mathrm{A}$ ', vitamin $\mathrm{B} 1, \mathrm{~B} 2$ and $\mathrm{B} 3$, vitamin ' $C$ ', vitamin ' $D$ ', vitamin ' $E$ ', vitamin ' $K$ ', Folate and Pantothemic acid (Zohary and Hopf, 2000).

Chickpea also contain many important minerals like as, Calcium, Iron, Molybdenum, Potassium, Manganese, Copper, Zinc etc. other nutrients that are found in chickpeas are dietary fibers water, etc.

The highest productivity of $3759 \mathrm{~kg} / \mathrm{ha}$ is observed in China followed by Israel, Republic of Moldova and Bosnia \& Herzegovina. India's productivity was 995 $\mathrm{kg} / \mathrm{ha}$ (FAO Stat. 2017).

Chickpea (Cicer arietinum L.) is known by different names in various countries such as gram, chana, bengalgram, kadle etc. Chickpea is an important Rabi season legume having extensive geographical distribution. Chickpea is the third most important pulse crop in the world after beans and peas.

It is cultivated on an area of 12 million hectares with 8.9 million tons of annual production. Chickpea plays an important role to improve soil fertility by fixing atmospheric nitrogen with the help of root nodules (Anabessa et al., 2009). Chickpea is native of south-eastern Turkey and Syria.

Seed priming is a pre-sowing strategy for influencing seedling development by modulating pre-germination metabolic activity prior to emergence of the radicle and generally enhances germination rate and plant performance (Bradford, 1986).

The main Objectives of Investigation is to assess the effect of different priming methods on growth, yield and its attributing characters of Chickpea, to determine the effect of different priming methods on seedling characters and to determine the Suitable priming method for chickpea.

The effectiveness of the priming with simple salt solution, perhaps, depends both on the osmotic potential and the chemical nature of the salt species used. It is reported that nitrate containing compounds may function more efficiently than other salts as priming agents. It has been found many salts can be used very effectively for priming.

\section{Materials and Methods}

The experiment was conducted in post graduate Seed Testing Laboratory, Department of Genetics and Plant Breeding, Sam Higginbottom University of Agriculture, Technology and Sciences, Pryagraj (U.P.) on Chickpea (var.Desi).

The treatments used at different concentrations viz., $\mathrm{T}_{0-}$ Unprimed Control, hydropriming- $\quad \mathrm{T}_{1^{-}} \quad$ Distilled water, osmopriming- $\mathrm{T}_{2}$ - Polyethylene Glycol (PEG) 5\%, $\mathrm{T}_{3}-$ Polyethylene Glycol (PEG) 7\%, $\mathrm{T}_{4-}$ Polyethylene Glycol (PEG) 9\%, halo priming$\mathrm{T}_{5}$ - Sodium Chloride ( $\left.\mathrm{NaCl}\right) 5 \%, \mathrm{~T}_{6}$ - Sodium Chloride $(\mathrm{NaCl}) 7 \%, \mathrm{~T}_{7}$ - Sodium Chloride $(\mathrm{NaCl})$ 9\%, $\mathrm{T}_{8}$ - Potassium Chloride $(\mathrm{KCl}) 5 \%$, $\mathrm{T}_{9}$-Potassium Chloride $(\mathrm{KCl}) 7 \%, \quad \mathrm{~T}_{10^{-}}$ Potassium Chloride (KCl) 9\%, Organic priming- $\mathrm{T}_{11^{-}}$Tulsi leaf extract $(5 \%), \mathrm{T}_{12-}$ Neem leaf extract (5\%).

After cleaning and grading, the seeds were soaked in respective priming solutions at different volume of seeds for twelve hours. Then the seeds were air dried under the shade to bring back to their original moisture content and used for sowing. 


\begin{tabular}{|c|c|c|c|}
\hline Symbol & Treatments & Concentrations & Duration \\
\hline $\mathbf{T}_{\mathbf{0}}$ & & - & - \\
\hline$T_{1}$ & $\mathrm{DH}_{2} \mathrm{O}$ & - & $12 \mathrm{hrs}$ \\
\hline $\mathbf{T}_{2}$ & PEG & $5 \%$ & $12 \mathrm{hrs}$ \\
\hline $\mathbf{T}_{3}$ & PEG & $7 \%$ & $12 \mathrm{hrs}$ \\
\hline $\mathbf{T}_{4}$ & PEG & 9\% & $12 \mathrm{hrs}$ \\
\hline $\mathbf{T}_{5}$ & $\mathrm{NaCl}$ & $5 \%$ & $12 \mathrm{hrs}$ \\
\hline $\mathbf{T}_{6}$ & $\mathrm{NaCl}$ & $7 \%$ & $12 \mathrm{hrs}$ \\
\hline $\mathbf{T}_{7}$ & $\mathrm{NaCl}$ & $9 \%$ & $12 \mathrm{hrs}$ \\
\hline$T_{8}$ & KCl & $5 \%$ & $12 \mathrm{hrs}$ \\
\hline$T_{9}$ & KCl & $7 \%$ & $12 \mathrm{hrs}$ \\
\hline$T_{10}$ & KCl & 9\% & $12 \mathrm{hrs}$ \\
\hline$T_{11}$ & Tulsi leaf extract & $5 \%$ & $12 \mathrm{hrs}$ \\
\hline$T_{12}$ & Neem leaf extract & $5 \%$ & $12 \mathrm{hrs}$ \\
\hline
\end{tabular}

\section{Prepration of solution}

For the preparation of solution one gram of each chemical was taken in a beaker. These chemicals were added separately in $1000 \mathrm{ml}$. of distilled water with constant stirring. The volume of solution was finally constituted to one liter, then it became 1000 ppm stock solution of each chemical. The flasks containing chemicals was covered with muslin cloth to avoid any contamination.

For the preparation of (5\%)Polyethylene glycol (PEG) solution 50 (g) PEG was taken in a measuring flask and made up to $1000 \mathrm{ml}$. distilled water, while Sodium chloride $\mathrm{NaCl}$ $5 \%$ ) solution $50(\mathrm{~g}) \mathrm{NaCl}$ was taken in a measuring flask and made up to $1000 \mathrm{ml}$. distilled water and $(5 \%)$ Potassium chloride $(\mathrm{KCl})$ solution $50(\mathrm{~g}) \mathrm{KCl}$ salt was taken in a measuring flask and made up to $1000 \mathrm{ml}$ with distilled water. Preparation of Neem leaf extract $(5 \%), 50(\mathrm{~g})$ powder of Neem leaf extract was taken in a measuring flask and made up to $1000 \mathrm{ml}$ distilled water and so on.

\section{Soaking of the seed solution}

After preparation of solution of Polyethylene glycol (PEG), Sodium chloride $(\mathrm{NaCl})$,
Potassium chloride ( $\mathrm{KCl})$, Tulsi Leaf Extract and Neem Leaf Extract, chickpea seeds were soaked in required solution for 12 hour at $25^{\circ} \mathrm{C}$ temperature. After $12 \mathrm{hr}$ of soaking the solution was drained out from the beaker and pre-soaked air dried to original weight and then placed for germination in laboratory under controlled condition. After the seed treatment seed was sown in field for occurring field observation. The observation on all growth and yield parameters viz., Field emergence percentage, days to $50 \%$ flowering, plant height at 30 and 60 DAS, number of branches per plant, number of pods per plant, seed yield per plant, seed yield per plot, biological yield and harvest index.

\section{Field emergence (\%)}

The field emergence count will be taken on the 4,7 and 10 days after the date of sowing and the emergence percentage was calculated, taking into account the number of seedlings emerged three centimetres above the soil surface.

\section{Days to 50\% flowering}

It will measure from DAS to half flowering, in which observe select five plants in a plot 
and check flowering status when $50 \%$ flower open in field.

\section{Plant height (cm)}

It was measured from ground level to the base of the top most fully opened leaf on 30 and 60 DAS. Average height of five plants was recorded in centimeters.

\section{Number of branches per plant}

In this method observe the total numbers of branch per plant from five randomly selected plants were counted manually from each plot.

\section{Number of pods per plant}

The total number of pods from five randomly selected plants was counted manually from each plot.

\section{Seed yield per plant (gm)}

The seed weight of five randomly select plants will be recorded of each plant in each plot.

\section{Seed yield per plot (gm)}

The seed weight of five randomly select plants will be recorded of each plot.

\section{Biological yield}

The biological yield refers to the total dry matter accumulation of a plant system. The biological yield of five randomly select plants will be recorded of each plot.

\section{Harvest index}

For grain crops, harvest index $(\mathrm{HI})$ is the ratio of harvested grain to total shoot dry matter, and this can be used as a measure of reproductive efficiency. The HI of five randomly select plants will be recorded of each plot.

$$
\text { HARVEST INDEX }(\%)=\frac{\text { GRAIN YIELD }}{\text { BIOLOGICAL YIELD }}
$$

\section{Results and Discussion}

A field experiment was conducted to study Effect of priming on the growth, yield, field attributing traits and seedling parameters on Desi Chickpea (Cicer arietinum L.) are as follows. The experiment was carried out during Rabi season 2018-19, Department of Genetics and Plant Breeding, Sam Higginbottom University of Agriculture, Technology and science, Prayagraj (U.P). The area is situated on the right side of the river Yamuna by the side of Allahabad Rewa Road about $5 \mathrm{~km}$ away from Allahabad city. The results are given and discussed under following headings.

Analysis of variance

Mean performance

\section{Analysis of variance}

The analysis of variance for growth and seed yield characters was presented in Table 1 . Analysis of variance revealed that the differences among thirteen treatments were significant for growth and yield, viz., field emergence percentage, days to $50 \%$ flowering, plant height at 30 and 60 DAS, number of branch per plant, number of pods per plant, seed yield per plant, seed yield per plot, biological yield, harvest index.

\section{Mean performance}

Mean value is defined by the ratio of the sum of the observations to the total number of observations. On other hand, range is the simplest measurement in mathematical calculation and simple to understand. It avoids variation of over all data and depends 
only on extreme values. The data presented in Table 1 shows mean performance of 13 treatments for 10 growth and yield parameters (quantitative). The grand mean for all the traits are also depicted in Table 1 and Table 2, respectively.

\section{Mean performance of growth and yield parameters}

\section{Effect of different priming methods on} field emergence percent

The mean performance of field emergence percent ranged from 79.67 to 92.67 with mean value of 86.38. Significantly highest field emergence percent (92.67) was reported in the priming with $\mathrm{T}_{3}$ Polyethylene Glycol (PEG) $7 \%$ and it was followed by $\mathrm{T}_{2}$ (91.33) with application of Polyethylene Glycol (PEG) $5 \%$ and $\mathrm{T}_{10}(90.00)$ with application Potassium chloride (KCl) 9\%. Minimumfield emergence percent was recorded by $\mathrm{T}_{0}$ (79.67) with control.

\section{Effect of different priming methods on days to $50 \%$ flowering}

The mean performance of days to $50 \%$ flowering ranged from 63.67 to 76.00 with mean value of 70.51. Significantly taken highest days to $50 \%$ flowering (76.00) was reported in $\mathrm{T}_{0}$ with control and it was followed by $\mathrm{T}_{1}$ (75.67) primed with distilled water and $\mathrm{T}_{7}$ (75.00) with application of Sodium chloride $(\mathrm{NaCl})$ 9\%.Minimumdays to $50 \%$ flowering was recorded by $\mathrm{T}_{3}$ (63.67) with application of Polyethylene Glycol (PEG) $7 \%$.

\section{Effect of different priming methods on plant height at $30 \mathrm{DAS}$}

The mean performance of plant height at 30 DAS ranged from $16.46 \mathrm{~cm}$ to $24.10 \mathrm{~cm}$ with mean value of $20.77 \mathrm{~cm}$. Plant height at 30
DAS observed significant, found to be highest $(24.10 \mathrm{~cm})$ in priming withT $\mathrm{T}_{3}$ Polyethylene Glycol (PEG) 7\%and it was followed by $\mathrm{T}_{2}$ $(23.46 \mathrm{~cm})$ with application of Polyethylene Glycol (PEG) 5\%and $\mathrm{T}_{10}(22.92 \mathrm{~cm})$ with application of Potassium chloride $(\mathrm{KCl})$ 9\%.Minimumplant height at 30 DAS was recorded by $\mathrm{T}_{0}(16.46 \mathrm{~cm})$ with control.

Effect of different priming methods on plant height at 60 DAS

The mean performance of plant height at 60 DAS ranged from $26.49 \mathrm{~cm}$ to $40.15 \mathrm{~cm}$ with mean value of $33.39 \mathrm{~cm}$. Plant height at 60 DAS observed non-significant, found to be highest $(40.15 \mathrm{~cm})$ in priming with $_{3}$ Polyethylene Glycol (PEG) 7\%and it was followed by $\mathrm{T}_{2}(38.90 \mathrm{~cm})$ with application of Polyethylene Glycol (PEG) 5\%and $\mathrm{T}_{10}(37.65$ $\mathrm{cm}$ ) with application of Potassium chloride (KCl) 9\%.Minimumplant height at 60 DAS was recorded by $\mathrm{T}_{12}(26.49 \mathrm{~cm})$ with application of Neem leaf extract @ 5\%.

\section{Effect of different priming methods on number of branches per plant}

The mean performance of number of branches per plant ranged from 4.03 to 7.60 with mean value of 5.72. Significantly highest number of branches per plant (7.60) was reported in the priming with $\mathrm{T}_{3}$ Polyethylene Glycol (PEG) $7 \%$ and it was followed by $\mathrm{T}_{2}$ (7.17) with application of Polyethylene Glycol (PEG) $5 \%$ and $\mathrm{T}_{10}$ (6.93) with application Potassium chloride $(\mathrm{KCl})$ 9\%. Minimumnumber of branches per plant was recorded by $\mathrm{T}_{0}(4.03)$ with control.

\section{Effect of different priming methods on number of pods per plant}

The mean performance of number of pods per plant ranged from 24.63 to 40.13 with mean value of 32.77. Significantly highest number 
of pods per plant (40.13) was reported in the priming with $\mathrm{T}_{3}$ Polyethylene Glycol (PEG) $7 \%$ and it was followed by $\mathrm{T}_{2}$ (38.67) with application of Polyethylene Glycol (PEG) $5 \%$ and $\mathrm{T}_{10}(37.40)$ with application Potassium chloride $(\mathrm{KCl}) 9 \%$. Minimum number of pods per plant was recorded by $\mathrm{T}_{0}$ (24.63) with control.

Effect of different priming methods on seed yield per plant (gm)

The mean performance of seed yield per plant ranged from $4.57 \mathrm{gm}$ to $8.70 \mathrm{gm}$ with mean value of $6.35 \mathrm{gm}$. Significantly highest seed yield per plant $(8.70 \mathrm{gm})$ was reported in the priming with $\mathrm{T}_{3}$ Polyethylene Glycol (PEG) $7 \%$ and it was followed by $\mathrm{T}_{2}(8.11 \mathrm{gm})$ with application of Polyethylene Glycol (PEG) $5 \%$ and $\mathrm{T}_{10}(7.70 \mathrm{gm})$ with application
Potassium chloride (KCl) 9\%.Minimumseed yield per plant was recorded by $\mathrm{T}_{0}(4.57 \mathrm{gm})$ with control.

\section{Effect of different priming methods onseed yield per plot (gm)}

The mean performance of seed yield per plot ranged from $673.16 \mathrm{gm}$ to $1158.27 \mathrm{gm}$ with mean value of $857.50 \mathrm{gm}$. Significantly highest seed yield per plot (1158.27 gm) was reported in the priming with $\mathrm{T}_{3}$ Polyethylene Glycol (PEG) 7\% and it was followed by $\mathrm{T}_{2}$ $\left(\begin{array}{ll}1075.31 & \mathrm{gm}\end{array}\right)$ with application of Polyethylene Glycol (PEG) 5\% and $\mathrm{T}_{10}$ (1023.65 gm) with application Potassium chloride $(\mathrm{KCl})$ 9\%. Minimumseed yield per plot was recorded by $\mathrm{T}_{0}(673.16 \mathrm{gm})$ with control.

Table.1 Analysis of variance for 9quantitative characters in chickpea

\begin{tabular}{|c|c|c|c|c|}
\hline \multirow{2}{*}{ S.No. } & \multicolumn{2}{|c|}{ Characters } & \multicolumn{3}{|c|}{ Mean sum of square } \\
\cline { 3 - 5 } & & $\begin{array}{c}\text { Replications } \\
(\mathbf{d f = 2})\end{array}$ & $\begin{array}{c}\text { Treatments } \\
(\mathbf{d f}=\mathbf{1 2})\end{array}$ & $\begin{array}{c}\text { Error } \\
(\mathbf{d f = 2 4})\end{array}$ \\
\hline $\mathbf{1 .}$ & Field Emergence percentage & 23.15 & $50.05^{*}$ & $\mathbf{0 . 9 3}$ \\
\hline $\mathbf{2 .}$ & Days to 50\% Flowering & 38.03 & $57.48^{*}$ & $\mathbf{7 . 9 1}$ \\
\hline $\mathbf{3 .}$ & Plant height at 30 DAS & 1.04 & $16.65^{*}$ & $\mathbf{0 . 1 4}$ \\
\hline $\mathbf{4 .}$ & Plant height at 60 DAS & 42.91 & 53.58 & $\mathbf{2 6 . 9 2}$ \\
\hline $\mathbf{5 .}$ & Number of Branch Per Plant & 0.41 & $3.65^{*}$ & $\mathbf{0 . 0 4}$ \\
\hline $\mathbf{6 .}$ & Number of Pods Per Plant & 57.69 & $70.96^{*}$ & $\mathbf{3 . 9 9}$ \\
\hline $\mathbf{7 .}$ & Seed yield per plant (g) & 0.01 & $5.04^{*}$ & $\mathbf{0 . 1 7}$ \\
\hline $\mathbf{8 .}$ & Seed yield per plot (g) & 1561.21 & $70981.65^{*}$ & $\mathbf{5 3 1 . 3 6}$ \\
\hline $\mathbf{9 .}$ & Biological yield & 935.43 & $139875.42^{*}$ & $\mathbf{4 7 5 4 . 6 9}$ \\
\hline $\mathbf{1 0 .}$ & Harvest index & $\mathbf{0 . 3 7}$ & $\mathbf{4 6 . 1 1 ^ { * }}$ & $\mathbf{0 . 7 3}$ \\
\hline
\end{tabular}

* significant at $5 \%$ level of significance 
Table.2 Mean performance of chickpea for 10 quantitative chickpea

\begin{tabular}{|c|c|c|c|c|c|c|c|c|c|c|c|}
\hline S.NO. & $\begin{array}{c}\text { Treatme } \\
\text { nts }\end{array}$ & $\begin{array}{c}\text { Field } \\
\text { Emergence } \\
\text { percentage }\end{array}$ & $\begin{array}{l}\text { Days to } \\
50 \% \\
\text { Flowering }\end{array}$ & $\begin{array}{c}\text { Plant } \\
\text { height at } \\
\text { 30 DAS }\end{array}$ & $\begin{array}{l}\text { Plant } \\
\text { height at } \\
60 \text { DAS }\end{array}$ & $\begin{array}{c}\begin{array}{c}\text { Number } \\
\text { of } \\
\text { Branch }\end{array} \\
\text { Per Plant }\end{array}$ & $\begin{array}{c}\text { Number } \\
\text { of Pods } \\
\text { Per } \\
\text { plant }\end{array}$ & $\begin{array}{c}\text { Seed } \\
\text { yield per } \\
\text { plant }(g)\end{array}$ & $\begin{array}{c}\text { Seed } \\
\text { yield per } \\
\text { plot }(\mathrm{g})\end{array}$ & $\begin{array}{c}\text { Biologic } \\
\text { al yield }\end{array}$ & $\begin{array}{c}\text { Harvest } \\
\text { index }\end{array}$ \\
\hline 1 & $\mathbf{T}_{\mathbf{0}}$ & 79.67 & 76.00 & 16.46 & 30.37 & 4.03 & 24.63 & 4.57 & 673.16 & 2311.12 & 29.12 \\
\hline 2 & $\mathbf{T}_{1}$ & 80.33 & 75.67 & 17.87 & 31.50 & 4.50 & 26.43 & 4.90 & 697.97 & 2304.13 & 30.25 \\
\hline 3 & $\mathbf{T}_{2}$ & 91.33 & 64.33 & 23.26 & 38.90 & 7.17 & 38.67 & 8.11 & 1075.31 & 2672.47 & 40.15 \\
\hline 4 & $\mathbf{T}_{3}$ & 92.67 & 63.67 & 24.10 & 40.15 & 7.60 & 40.13 & 8.70 & 1158.27 & 2791.20 & 41.38 \\
\hline 5 & $\mathbf{T}_{4}$ & 89.33 & 67.00 & 22.67 & 36.50 & 6.57 & 36.77 & 7.31 & 968.46 & 2469.95 & 39.11 \\
\hline 6 & $\mathbf{T}_{5}$ & 86.00 & 70.33 & 21.20 & 27.63 & 5.47 & 32.60 & 6.07 & 810.67 & 2176.83 & 37.21 \\
\hline 7 & $T_{6}$ & 84.67 & 73.67 & 19.74 & 33.71 & 5.07 & 30.80 & 5.62 & 762.60 & 2160.93 & 35.17 \\
\hline 8 & $\mathbf{T}_{7}$ & 82.33 & 75.00 & 18.34 & 32.43 & 4.77 & 27.70 & 5.08 & 738.33 & 2253.52 & 32.66 \\
\hline 9 & $\mathbf{T}_{8}$ & 87.67 & 69.33 & 21.73 & 30.00 & 5.90 & 34.60 & 6.40 & 814.79 & 2116.48 & 38.46 \\
\hline 10 & $\mathbf{T}_{9}$ & 89.00 & 68.67 & 22.20 & 35.80 & 6.13 & 35.20 & 6.76 & 897.40 & 2297.01 & 38.92 \\
\hline 11 & $\mathbf{T}_{10}$ & 90.00 & 66.00 & 22.92 & 37.65 & 6.93 & 37.40 & 7.70 & 1023.65 & 2566.48 & 39.86 \\
\hline 12 & $T_{11}$ & 84.33 & 74.67 & 18.75 & 32.90 & 4.90 & 29.50 & 5.36 & 754.13 & 2245.81 & 33.44 \\
\hline 13 & $T_{12}$ & 85.67 & 72.33 & 20.77 & 26.49 & 5.30 & 31.53 & 5.91 & 772.80 & 2119.62 & 36.28 \\
\hline \multicolumn{2}{|c|}{ Grand Mean } & 86.38 & 70.51 & 20.77 & 33.39 & 5.72 & 32.77 & 6.35 & 857.50 & 2345.04 & 36.31 \\
\hline \multicolumn{2}{|c|}{ C.D. $(5 \%)$} & 1.63 & 4.74 & 0.63 & 8.75 & 0.35 & 3.37 & 0.69 & 38.85 & 116.20 & 1.44 \\
\hline \multicolumn{2}{|c|}{ SE(m) } & 0.56 & 1.62 & 0.22 & 3.00 & 0.12 & 1.15 & 0.24 & 13.31 & 39.81 & 0.49 \\
\hline \multicolumn{2}{|c|}{ SE(d) } & 0.79 & 2.30 & 0.31 & 4.24 & 0.17 & 1.63 & 0.33 & 18.82 & 56.30 & 0.70 \\
\hline \multicolumn{2}{|c|}{ C.V. } & 1.12 & 3.99 & 1.81 & 15.55 & 3.66 & 6.10 & 6.45 & 2.69 & 2.94 & 2.35 \\
\hline \multicolumn{2}{|c|}{ F.Test } & $\mathrm{S}$ & $\mathrm{S}$ & $\mathrm{S}$ & NS & $\mathrm{S}$ & $\mathrm{S}$ & $\mathrm{S}$ & $\mathrm{S}$ & $\mathrm{S}$ & $\mathrm{S}$ \\
\hline
\end{tabular}


Effect of different priming methods on biological yield

The mean performance of biological yield ranged from 2311.12 to 2791.20 with mean value of 2345.04. Significantly highest biological yield (2791.20) was reported in the priming with $\mathrm{T}_{3}$ Polyethylene Glycol (PEG) $7 \%$ and it was followed by $\mathrm{T}_{2}(2672.47)$ with application of Polyethylene Glycol (PEG) 5\% and $\mathrm{T}_{10}(2566.48)$ with application Potassium chloride $(\mathrm{KCl}) 9 \%$. Minimum biological yield was recorded by $\mathrm{T}_{0}$ (2311.12) with control.

\section{Effect of different priming methods on harvest index}

The mean performance of harvest index ranged from $29.12 \%$ to $41.38 \%$ with mean value of $36.31 \%$. Significantly highest harvest index (83.50) was reported in the priming with $\mathrm{T}_{3}$ Polyethylene Glycol (PEG) 7\%and it was followed by $\mathrm{T}_{2}(40.15 \%)$ with application of Polyethylene Glycol (PEG) 5\% and $\mathrm{T}_{10}$ (39.86\%) with application Potassium chloride (KCl) $9 \%$.

Minimum harvest index was recorded by $\mathrm{T}_{0}$ (29.12\%) with control.

\section{Summary}

An investigation was carried out to evaluate the "Effect of priming on the growth, seedling, yield and its attributing characters on Desi Chickpea (Cicer arietinum L.)"

All growth and yield parameters viz., Field emergence percentage, days to $50 \%$ flowering, plant height at 30 and 60 DAS, number of branches per plant, number of pods per plant, seed yield per plant, seed yield per plot, biological yield and harvest index.

The results obtained from the present investigation are summarized below.
Field emergence, growth and yield attributes

Field emergence percent (92.67\%) were highest in $\mathrm{T}_{3}$ - Polyethylene Glycol (PEG) @ $7 \%$ followed by $\mathrm{T}_{2}-$ Polyethylene Glycol (PEG) @ 5\% (91.33\%) and found to be lowest in $\mathrm{T}_{0^{-}}$Control (79.67\%). Days to 50\% flowering (76.00) were highest in $\mathrm{T}_{0^{-}}$Control followed by $\mathrm{T}_{1}$ - Distilled water (75.67) and found to be lowest in $\mathrm{T}_{3}$ - Polyethylene Glycol (PEG) @ 7\% (63.67). Plant height at 30 DAS $(24.10 \mathrm{~cm})$ were highest in $\mathrm{T}_{3}$ - Polyethylene Glycol (PEG) @ 7\% and found to be lowest in $\mathrm{T}_{0^{-}}$Control $(16.46 \mathrm{~cm})$. Plant height at 60 DAS $(40.15 \mathrm{~cm})$ were highest in $\mathrm{T}_{3}$ Polyethylene Glycol (PEG) @ 7\% and found to be lowest in $\mathrm{T}_{0^{-}}$Control $(30.37 \mathrm{~cm})$. Number of branches per plant (7.60) were highest in $\mathrm{T}_{3}$ - Polyethylene Glycol (PEG) @ $7 \%$ and found to be lowest in $\mathrm{T}_{0^{-}}$Control (4.03). Number of pods per plant (40.13) were highest in $\mathrm{T}_{3}$ - Polyethylene Glycol (PEG) @ $7 \%$ followed by $\mathrm{T}_{2}$ - Polyethylene Glycol (PEG) @ 5\% (38.67) and found to be lowest in $\mathrm{T}_{0^{-}}$Control (24.63). However yield attributes were also positively influenced by osmoprimed seed treatment and highest seed yield per plant and seed yield per plot (8.70 $\mathrm{gm}, 1158.27 \mathrm{gm}$ ) respectively were highest in $\mathrm{T}_{3}$ - Polyethylene Glycol (PEG) @ 7\% and found to be lowest in $\mathrm{T}_{0^{-}}$Control $(4.57 \mathrm{gm}$, $673.16 \mathrm{gm})$ respectively. Biological yield (2791.20 gm) was highest in $\mathrm{T}_{3}$ - Polyethylene Glycol (PEG) @ 7\% and found to be lowest in $\mathrm{T}_{0^{-}}$Control (2311.12 gm). Harvest index $(41.38 \%)$ was highest in $\mathrm{T}_{3}$ - Polyethylene Glycol (PEG) @ 7\% followed by $\mathrm{T}_{2^{-}}$ Polyethylene Glycol (PEG) @ 5\% (40.15\%) and found to be lowest in $\mathrm{T}_{0^{-}}$Control $(29.12 \%)$.

In conclusion the priming increases the germinability and vigour of chickpea seeds, significantly all the field parameters. Osmopriming with PEG significantly 
increased the germination per cent and other seedling characters of chickpea. Osmopriming with PEG @7\% showed maximum increase in germ inability and vigour and showed maximum increase in germination. Priming of the chickpea seeds for $12 \mathrm{hrs}$, in which PEG @ 7\% best result to enhanced germinability, vigour and seedling characters. These conclusions are based on the results of six months investigation and therefore further investigation is needed to arrive at valid recommendations.

\section{Acknowledgement}

The authors are thankful to all the members of the teaching and non-teaching staff of the Department of Genetics and Plant Breeding, Sam Higginbottom University of Agriculture, Technology and Sciences, Prayagraj, U. P., for providing all necessary facilities and support.

\section{References}

Aghbolaghi, and M. A. Md. Sedghi,(2014).The Effect of Osmo and Hormone Priming on Germination and Seed Reserve Utilization of Millet Seeds under Drought Stress. Journal of Stress Physiology \& Biochemistry, 10(1): 214-221.

Ali, U. A., Tareen, S., Md. JavedAli., Ijaz, T. and Md. Naveed., (2012). Effects of Seed Priming on the Antioxidant Enzymes activity of Mungbean (Vigna radiata) Seedlings. Pakistan Journal of Nutrition, 11(2): 140 .

Anbessa, Y., Taran, B., Warkentin, T. D., Tullu, A., and Vandenberg, A. (2009). Genetic analyses and conservation of QTL for ascochyta blight resistance in chickpea (Cicer arietinum L.). Theor. Appl. Genet. 119, 757-765. doi: 10.1007/s00122009-1086-2

Anon, (1999).AOAC International qualitative and quantitative microbiology guidelines for methods validation. J. AOAC Int., 82, 40216.
Ashraf $M$ and Rauf H. (2001). Inducing salt tolerance in maize (Zea mays L.) through seed priming with chloride salts: Growth and ion transport at early growth stages. Acta Physiol Plant, 23: 407-417.

Assefa, K.R., Hunje, R., Koti, R.V. and Biradarpatil, N.K. (2008). Effect of seed priming on storability, seed yield and quality of soybean [Glycine max (L.)Merill]. University of agricultural Science, Dharwad (M.S.) INDIA.

Bajpai, V. P., Khan, A. A., Vyas, R. P., Tiwari and Tripati, R. Q., (2002). Effect of bio insecticides on viability of urd bean seed (Vigna mungo L) stored in different containers. Seed Research, 30(2): 331-333.

Baki A, and Anderson JD. (1973). Vigor determination in Soybean seed by multiple criteria. Crop Sci. 13: 630-633.

Basra, S. M. A., Zia, M. N., Mahmood, T., Afzal, I. and Khaliq, A., (2003).Comparison of different invigoration techniques in wheat (Triticum aestivum L.) seeds. Pakistan Journal of Arid Agriculture, 2:11-16.

Bradford K.J., (1986).Manipulation of seeds water relation via osmotic priming to improve germination under stress condition. Horticulture Science, 59(2): 672-676.

Chavan N. G., Bhujbal G. B. and Manjare M. R. (2014). Effect of Seed Priming on Field Performance and Seed Yield of Soybean [GLYCINE MAX (L.)MERILL] varieties. 9(1): 111-114

Chojnowski, M., Corbineau, F. and Come, D., (1997).Physiological and biochemical changes induced in sunflower seeds by osmopriming and subsequent drying, storage and aging. Seed Science and Research, 7: 323-331.

Demir, I., and Oztokar, C., (2003). Effect of salt priming on germination and seedling growth at low temperature in watermelon seed during development. Seed Science and Technology, 31: 765-770.

Elouaer, M. A and Hannachi, C., (2012). Seed priming to improve germination and seedling growth of safflower (Carthamus tinctorius) under salt stress. EurAsian Journal of BioSciences, 6: 76-84.

FAOSTAT (2017).http://faostat.fao.org/

Fisher, R.A. (1936). The correlation between 
relative on the supposition of genotypes grown in Kumaun Himalaya, Indian Journal Genetics. 66(1): 37-38.

Jie, L., Gong, She. L., Dong, Mei. O., Fang, Fang, L. and En, Hua. W. (2002).Effect of PEG on germination and active oxygen metabolism in wild rye (Leymus chinensis) seed.Actaprataculturaesinica.1159-64.

Khan, M. S., Chaudhry, P., Wani, P. A., and Zaidi, A., (2006). Biotoxic effects of the herbicides on growth, seed yield, and grain protein of greengram (Vigna radiata) L. Journal of Applied Sciences and Environmental Management, 10(3): 141146.

Mehta, D. IC, Kanwar, H. S., Thakur, A. K. and Thakur, K. S., (2010).Influence of organic seed priming on germination and seedling quality in bell pepper (Capsicum annuum L.). Journal of Hill Agriculture, 1(1): 85-87.

Nagar, R. P., Dadlani, M. and Sharma, S. P., (1998).Effect of hydropriming on field emergence and crop growth of maize genotypes. Seed Science Research, 26: 1-5.

Nawaz, J., Hussain, M., Jabbar, A., Nadeem, G. A., Sajid, M., Mashood, U. Subtain and Shabbir, I., (2013). Seed Priming A Technique. International Journal of Agriculture and Crop Sciences, 6(20): 1373-1381.

Ruan S., Q. Xue and Tylkowska, K. (2002). The influence of priming on germination of rice Oryza sativa L. seeds and seedling emergence and performance in flooded soil. Seed Science \& Technology, 30: 61-67.

Sedghi, M., Nemati, A. and Esmaielpour, B., (2010). Effect of seed priming on germination and seedling growth of two medicinal plants under salinity. Emirates Journal of Food and Agriculture, 22 (2): 130-139.

Singh, C. B., Kumar, M., Poonam Singh and Vyas, R. P., (2006).Studies in Relative Efficiency of Neem Based Bio-insecticides on Germination, Seedlinng length and Seed Vigour index in Pigeon Pea Seed. XIII National Seed Seminar, 127.

Umair, A., Safdar Ali., Muhammad Sarwar., Kashif Bashir., Muhammad Javed Tareen and Muhammad Asghar Malik., (2013). Assessment of Some Priming Techniques in Mungbean (Vigna radiate): a Green House Study. Pakistan Journal of Agricultural Research, 26(4): 265-274.

Yari, L., Aghaalikani, M. and Khazaei, F. (2010).Effect of seed priming duration and temperature on seed germination behaviour of bread wheat (Triticum aestivum L.). ARPN J Agric Biol Sci.5: 1.

Zohary D, and Hopf M (2000).Pulses. In: Domestication of plants in the old world: the origin and spread of cultivated plants in West Asia, Europe, and the Nile Valley, 3rd edn. Oxford University Press, New York, pp. 108-111.

\section{How to cite this article:}

Nelakurthi Venkata Praveen, Prashant Kumar Rai, Rupesh Kumar and Ruksana. 2020. Effect of Priming on the Growth, Seedling, Yield and its Attributing Characters of Desi Chickpea (Cicer arietinum L.). Int.J.Curr.Microbiol.App.Sci. 9(09): 3162-3171. doi: https://doi.org/10.20546/ijcmas.2020.909.391 